\title{
Increasing Women's Role in the Democratic Process: Lessons Learned from Thailand's 1997 Constitutional Reform and Thailand's 2001 General Election
}

\author{
Irhamna \\ Department of Political Science \\ Faculty of Social and Political Sciences, Universitas Indonesia, Indonesia \\ irhamna.irham@gmail.com/irhamna51@ui.ac.id
}

\begin{abstract}
This article examines the role of Women and Constitution Network (WCN) in Thailand's 1997 constitutional legislation process. To be specific, the introduction of gender equality article, and its application in Thailand's 2001 General Election. This study uses qualitative methods to analyze the role of WCN in the legislation process of gender equality article. This study finds the law of gender equality is givin an opportunity to increase women political participation in Thailand. Through the constitutional guarantee of gender equality and support from civil society organizations, women's political participation is increased in Thailand's 2001 General Election.
\end{abstract}

Keywords: women, political participation, gender equality, civil society organizations, constitution, Thailand

\section{INTRODUCTION}

Since the beginning of Women's Decade which marked with the resolution of Beijing Platform 1995, women issues has became more attractive, especially when we talked about democratization and democratic process within a state. Democratization is giving more space for participation that should be used by women. One of the main issues here is women's political participation. Women is always placed as marginalized groups when it comes to politics or power, they had been excluded from policy making process. Though, there are no differences between man and woman, they shared the same rights, including the right to participate in politics.

As a country that has just begun their democratization after the end of Cold War, women's political participation became the major issue that been talked around. Because, Thailand is well-known as a Buddhist-state, and the value of Buddhism are not considered as 'women friendly'. Buddhism became one of the determinant factors of women exclusion in public sphere. There are three levels of human activities according to Buddhism: First, Religious Activity, the highest one.

This level is only for man, they did not recognize woman existence, therefore We could not find any Bhikkuni (Women Monk). Contrary to Myanmar, Thailand do not allowed women to become a monk. Second level is for SocialPolitical Activity, in this level, women are not the main actors, they simply did not get the spotlight. If men were being too dominant in the first two levels, Thailand's women steal the third one, Economic Activity. They are known as a good traders, and became the lord of trading sector (Ockey, 1999)i.

The institutionalization of democracy has made several inevitable political implications, for instance the emergence of electoral democracy, and it also reflected on Thailand's constitutional reform. Thailand became a constitutional moncarchy since 1932, until now, Thailand has been changed their constitution for 16 times (Ockey, 1997). However, there are plenty aspects that left unmanaged, like women's political particiaption. Fortunately, they realized that women shall actively participate in politics. In doing so, they have committed to increase women's political participation as the new main goal in 1997 Constitution.

In order to increase women's political participation, there are several requirements that need to be fulfilled. Women issues had successfully penetrate the local discourse, powered by women's movement across the country. Later, they unified and create a communication network called Women's 
Constitution Network (WCN) $)^{\mathrm{ii}}$, and became the actor behind the increase of women's political participation and representation.

Thailand's 1997 Constitution is also known as People's Constitution (Kuhonta,2008), and marked the establishment of new regime in Thailand's history, a more democratic government. The main reason of why 1997 Constitution being called as People's Constitution iii is because the democratic process behind it. The constitution was written in such deliberatively way, allowed all citizen to take a part in constitution making process. The draft was prepared by an independent ad-hoc agency, Constitution Drafting Assembly (CDA). CDA's members ares representatives from all provinces and combined with the brilliant mind from the professors (Ockey, 1997). The recruitment process of CDA'siv has opened up more room for participation in Thailand, especially for women.Communication network that WCN's been build amongst women's groups create such possibilities for resource mobilization, and they can achieved the equality goals thus increased their political participation. The problem is, how strong are they to influence women's political participation and what kind of role that they played?

Thailand's women had gained their suffrage since the First Constitution been implemented at 1932. Yet, they still have to face cultural obstacles to be more actively participated in political process. Thailand's women are still trapped under the pathriarcy value. The first woman MP was elected at 1949 General Election, until the 1952 General Election there were only four women who served as MP. In the next five decade 1949-2000, there was no significant improvement of women representation in Parliament. Even in the South East Asia region, they were consistently low, $9,2 \%$ in average for women in Parliament, when the other countries were around $14 \%$ in average.2001 General Election is the first election that implemented 1997 Constitution. As a constitution which granted the gender equality, many people put a high hopes, there will be a significant change in women's political participation, especially for women representation in Parliament (Iwanaga, 2005).
The shifting from direct democracy to representative democracy had changed the paradigm of representation from who are they represented into what are they represented. Recently, the debate over representative democracy is focused on the demand for equality in political presence both of men and women. Politics of idea is getting a new challenge when it comes to the importance of political presence of policy making process (Phillips, 1995: 4-5). The presence of women in Parliament will provide another perspective to influence the policy formulation. Elected women are not only stand for women but also act for women (Norris, 2004).

The formulation of 1997 Constitution was marked as a small improvement towards a more participative environment for women participation. Popular constitution making through CDA has succeed to guarantee the gender equality. It took years of advocacy and political education in all level, which implemented by Women's Constitution Network.

The 1997 Constitution was used for the first time at 2001 General Election. The result is quite unpredictable. Female MP's gained 9,2\% of total seats in Lower House, it equals as 46 seats. Since Thailand was using Multi-Member Majoritarian (MMM) as her election system, therefore 39 women MP was elected through Single-Member Constituency (SMC), and the rest through party-list system (open-list proportional) (Vichit-Vadakan, 2008). The total number $9,2 \%$ for Thailand is a big number, even the average in South East Asia is around 14\% that time. If we compared to the 1996 General Election, there was around 3,6\% increase of women representation in Parliament, and it was the biggest margin ever in Thailand Constitutional Monarchy's history, and if we talked about number, at the last election there were only 22 women MP's in Parliament, but in 2001 General Election, there were 46 women MP's, it had grow more than twice.

As we know that The 1997 Constitution, or in its official name is called Constitution of the Kingdom of Thailand B.E. 2540 was the first constitution that introduced the gender equality article, explicitly in Article 5 stated that : "The Thai people, irrespective of their origins, sexes, or religions, shall enjoy equal protection under this 
Constitution". The implication of this article is considered as the protection of women involvement in politics, in broaden context, state is addressing full responsibility from any kind of threats towards Thai's. We can also find another justification in Article 30 :

\begin{abstract}
"All persons are equal before the law and shall enjoy equal protection under the law. Men and Women shall enjoy equal rights. Unjust discrimination against a person on the grounds of the difference in origin, race, languange, sex, age, or health condition, personal status, economic or social standing, religious belief, education or constutionally political view shall not be permitted. Measures determined by the State in order to eliminate obstacle to or to promote persons' ablilty to excercise their rights and liberties as other persons shall not be deemed as unjust discrimination under paragraph three"
\end{abstract}

According to those backgrounds, the research are aim to describe and analyze the role of Women and Constitution Network in the legislation process of gender equality artlicle in 1997 Constitution, and the increase of women political representation in 2001 General Election. The research will be focused on the legislation process and its dynamics, and how they will be implementedin the election.

Nowaday, research on women political participation in Thailand is limited to success story of Thailand's women movement for the legislation of gender equality article. I tried to analyze the impact of gender equality article towards the rise of women representation in Parliament. I also want to describe several factors that influenced women increase their participation in policy making process, they believed in deliberative process which I found interesting.

In order to analyze such factors, this research will use several concepts: political opportunity structure (POS), politics of presence, and election system. Opp (2009:161) defines POS as changes in the political environment that influence the chance of success. This perspectives become dominant and edged out the resource mobilization perspective which was dominated in the early 1970. POS is also known as political process model, since its emphasizes on process that surrounded the activities. Einsinger (1973, see Opp, 2009) defines the concept of political opportunities as follows: the context within which politics takes place called the stucture of political opportunities. Einsinger also lists some macro factors called political opportunity structures such as governmental responsiveness which more or less promote the attainment of individual goals, therefore increase the chances of success of citizen political activity.

The concept of politics of presence (see Philips, 1995) lies in the notion that the problems of political exclusion have several dimensions. We can see through election system, one group that well represented while the others suffered under-representation. We can also see through access to political participation, which somehow divided into class-based. Those conditions explained as if society live under political absence. The shifting paradigm from direct democracy to representative democracy had successfuly changed "who' into "what". We were not longer talking about who is represents us, yet we concerned about what are they represents? The debate of representative democracy is often focused on the demand of equality in political presence, since the politcs of idea was challenged by this idea. The presence of women MPs in parliament will give another perspectives in the articulation process, the elected women will not only stand as women but also act for women (Norris, 2004:179).

Electoral system is often cited as one of the key factor that determine the women representation in parliament. There are so many types but we can simplified it into three major systems: majoritarian (plurality), proportional (open-list/party-list), and mixed systems. Tremblay (2008) argues that women faced structural constraints when it comes to majoritarian rules. Why so? In majoritarian, each electoral district is only has one seat, and it depends on majority votes, and the winner takes all. Political party will rationally chose or placed their most promising candidate to win the election, unfortunately due to the several unjust act towards women, and other barriers for instance the political culture and patriachic society, it had been very hard for women to compete in such condition. The proportional system give more advantages to women, since the party get to choose and offer candidates diversly from socio-demographic to ideologic (Tremblay, 2008). 
Tremblay explained how the cultural, socio-economics, and political factors could developed women political participation. In socalled cultural factor, the conception of equality of men and women played a dominant role, as welfare in socio-economics. Yet, the most important factors is the political factor which consists of: women political right, and political regime. Women political right can be managed by the time that they gained the women suffrage, so they can maintain their rights afterwards. The dimension of political regime will defined as parliament structure, party systems, and electoral systems. He is also argues that women proportions in parliament is a result of the interaction of cultural, socio-economic, dan political factors. Women's proportion in parliament can also be seen as interactional function of electoral system, political party, and quotas.

In this research, I will use qualitative methods to explain the findings. I chose literature review and analyzed related documents, since I have faced sort of financial limitation to conduct this research outside my country. All the data that I have been gathered can solemnly classifed as secondary data.

\section{Socio-Political Context of Women's Political Participation in Thailand}

Thai's people is considered homogenous which dominated $75 \%$ by Thai ethnic, $14 \%$ by Chinese, and the rest are some relatively small ethnic groups such as Malay (Banks, 2009). According to the National Census in 2000, total population in Thailand was around 61 milion peoples, and nearly one-sixth lived in Bangkok Metropolitan Region (Smith, 2005: 293). Thai's is domintantly Buddhist, around $95 \%$ of its population believed in Theravada Buddhism.

One of the most notable consequences in Thailand's political history were coup de' etat. A vicious cycle that has been repeated until today. There were 17 times coup has been staged in Thailand by civilian as well as military force. Politics in Thailand became more interesting when women participation increased, since they known as Buddhist country which value the patricarchy, resulting women exclusion from public sphere.
Pasuk Pongpaichit, one of notable political scienctist stated that Thailand passed through democratic transisiton dramatically (Pongpaichit and Baker, in Hewison, 1997: 21). He emphasized term 'dramatically' to describe how the political power contested by many elements such as military, civilian, and burueaucracy. The change has begun in 1932, when The Kingdom of Thailand decided to change its basic from absolute monarchy to constitutional monarchy (Wasi, in McCargo, 2002: 21). After the establishment of 1932 Constitution, bureaucracy and military forces shared relatively balanced influence in Thailand's politics, which later lead to bureaucratic-authoritariansm. A little background to bureaucrat, in Thailand they called as mandarin a powerful social group which gained material wealth and power through their loyalties to the ruler king. They may sound like what we called as patron-client relation.

Power interplay between civil-bureaucrat and military was getting stronger before the drafting process begun. It was related to such riot which happened at May 1992, often refers as Bloody May. The main reason was inconstitutional power-taking by General Suchinda Kraprayoon, then lead to hundreds of protest, and tied up by repressive action from military. It started when The 1991 Constitution has been implemented, one of its clause stated that there is a possibility for Prime Minister-elect is a non-partisan. The clause has made as justification by General Krapayoon to selfappointed himself as the new Prime Minister. We can learn that Thailand's Constitution is weak, and increasing the chance of being thrown by the new regime.

Those condition above has made Prawase Wasi, who was also a notable academia, to push several changes in political realm of Thailand. He persistenly argue that Parliament should amended Article 211 in 1992 Constitution, in order to compose a new constitution. His action then lead into the development of Democracy Development Comittee (DDC) (Wasi, in McCargo, 2002: 23). DDC was established in 9th June 1994, and was formally dissolved in 28th April 1995. During that time, DDC was aimed to compose a new constitution. DDC was headed directly by Mr. Wasi. Even when they had a clear and tangible vision, their activities were not 
supported by the politician. The politician assumed what DDC was doing could interfere their power in Parliament. DDC overcome this problem with a strong media relation, they succesfully attract public attention, and raise this issue from just a simple demand of political reform into a wave of social movement.

The dissolution of Parliament in 1995 was followed by the general election. In 1995 General Election, political reform became the main issue that been discussed by all parties, especially when the notion of composing the new constitution. Banharn Silpa-archa from Cart Thai Party was using this issue in his campaign. He made a promise that when he took the office, he would implemented the political reform thourgh constitutional reform. They had succeded to take the office, and PM Banharn was committed to his promise, and completed it by the establishment of Political Reform Committee (PRC). The committee gave a recommendation to amend the Article 211. After the process in Parliament, Constitution Drafting Assembly (CDA) was promulgated as the constitution maker.

The history Thailand's women is quite different than other women in Southeast Asia, they had gained suffrage without any struggle, yet they had been alienated from public sphere due to the pathriarcic value of Buddhism. Darunee and Pandey (in Ockey, 1999: 1035)argued that women will always be a clients rather than a patrons. Other considered women's exclusion as lack of virtues. This view is not olny come from Theravada's Buddhism but also as an impact of syncretismfrom Hinduism, Animism, and Mahayana's. Neil Mulder (in Ockey, 1999: 1035) opposed the fact that women are lack of virtues, he argued that despite women are excluded and did not have the right for being a bhikkuni, it did not meant that they could be less wise than bhikku. Thai's women are often associated as virtous being, through khuna or moral goodness.

\section{Increasing Women Political Participation in Thailand}

Women political participatin can be divided into three periods. The first periode was started when King Rama V claimed the thorne in 1868, and was ended in 1932 when the first constitution was promulgated. The second period was around 1932-1975, as United Nation
(UN) introduced International Women Years. The last period was around 1976 until 2001. In the first period, women involvement were limited only to the advancement of political awareness. By the second period, when women already gained universal suffrage, they did have an equal constitution, The 1974 Constitution, unfortunately this constitution was only lasted a while. The interesting part was started in the Third Period. In this period, women's movements are started to rise above, they had left the underground methodv, and chose the advocacy path. I can say that the third period was the best for women empowerment in Thailand.

We can not deny the fact that the women representation in the Parliament is slowly rising. On the other side, there are still less women who held the strategic position in Parliament. Women are just used as a tools for political party to gain the vote. They were alianated from the authority which they had gained. One of the most notable factor is the clientelism, the relation between patrons and the clients. The party leader is not the only institution that can decide party's policy, there are some informal actors who guided party's policies. This informal actors are often disguised as financial donors and bussiness groups.

Thailand's Parliament is consists of 31 committees which oversee specific sections, and each of committee has 17 members. I have found some intriguing data showed that the women are still less represented in the strategic comittee, most of them are merely a member. The table below showed five committees which have most women members.

Table 1

Women as Standing Committee in Lower House after 2001 General Election

\begin{tabular}{|l|l|l|l|}
\hline Committee & $\begin{array}{l}\text { Total of } \\
\text { Women } \\
\text { MPs }\end{array}$ & Percentage & Position \\
\hline $\begin{array}{l}\text { Women, } \\
\text { Children, Youth } \\
\text { and Elderly }\end{array}$ & 11 of 17 & $64,71 \%$ & $\begin{array}{l}\text { Chairwoman, Vice- } \\
\text { Chair, Secretary, } \\
\text { Spokeswoman }\end{array}$ \\
\hline $\begin{array}{l}\text { Parliamentary } \\
\text { Relation }\end{array}$ & 4 of 17 & $23,53 \%$ & Vice-Chairwoman \\
\hline Tourism & 5 of 17 & $29,41 \%$ & $\begin{array}{l}\text { Vice-Chairwoman, } \\
\text { Secretary, } \\
\text { Spokeswoman }\end{array}$ \\
\hline Public Health & 4 of 17 & $23,53 \%$ & Vice-Chairwoman \\
\hline
\end{tabular}


Table 1, cont.

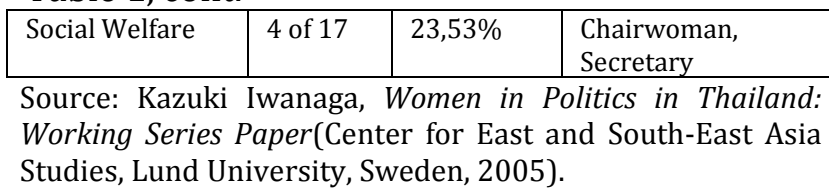

Things were not getting easier when women had secured their seats in the Office, they should be prepared as targeted bully, especially when they are being 'too feminist' while legislating a bill. This kind of labelling are just made things getting messier and harder for women, since they are currently transferred from privat to public sphere. On the contrary, when women MPs were acting 'a bit masculine' the other MPs did not labelled them as 'nonfeminist' or 'conflicting their nature'. This contradiction called double-binding as Bateson said, and it was used by the superior group to compress the influence of inferiors (Nelson and Nohlen, 2001: 265).

The advancement of women political participation can be seen from the legislation process of 1997 Constitution. The making of 1997 Constitution was a great leap forward in Thailand's democracy, because it was for the first time in their history that all of citizens can take their part in the so-called popular constitution making that institusionalized through CDA.

As I mentioned above, Women and Constitution Network (WCN) has vital role during the constitutional making in 1997. Through their network, 6.789 women has been registered to be a member of CDA, and it was about $35 \%$ of total CDA's member candidate. Why in all of sudden women political participation was skyrocketing? The answer is because the weakness of the party itself. They did not recognize women as a whole new political power, since the access were left open women took the chance and stood up. This implies that women are willing to be participated in policy making process, only if they had enough chance.

WCN with its top cadre whose elected as CDA's members has showed us how strong and powerful they are. They have offered the committee several articles related gender equality and human rights. It can also be seen as the rise of non-governmental organization (NGO) in Thailand. Shigetomi (2006) mentioned that the rise of WCN is also because the political party did not maximized the open cleavage, the other advantages is their populist-approach.

While the draft is being discussed by CDA, the members of WCN are also in their movement. They held several hearings and meetings, from town to town, asking the people what they really need in the new constitution. There are three articles, at least, that been initiated by WCN, even with the small numbers in CDA's committee. The three articles are: Article 30 concerning constitutional guarantee of gender equality, Article 53 related to family and child protection, and Article 80 about the role os state in promoting gender equality. Despite the women had already gained the suffrage and got the constitutional guarantee, their struggle was actually just begun. Women MPs are facing a new challenge, how to influence the Parliament with their perspective, and make Parliament more sensitive to gender issues.

I argue that 2001 General Election is a new milestone not only for women but also for electoral reform in Thailand. In 2001, Election Commission of Thailand (ECT) has introduced a new electoral system, Mixed-Member Majoritarian (MMM). Before the 2001 General Election they used Single Member Constituency (SMC). The MMM is a combination from SMC and Proportional Party-List System.

According to the data from ECT, there was 42.779.001 eligible voters in 2001 General Election. They have to choose their representatives for Lower House and Senate. Thailand are divided into 400 electoral districts, with average around 154.154 voters. There were 2.430 male candidates (equal to 83,75\%) and 352 female candidates (equal to 12,65\%). They were belong to 39 political parties which contested in 2001 General Election (Kokpol, 2001). I implied that the implementation of 1997 Constitution which guaranteed the gender equality, had several impacts towards the increase of women representation. As the result, 46 women MPs are elected, those numbers are equal to $9,2 \%$ of total seats in Lower House, and 21 women are succeded to take the Senate Office, and it equal to $10,5 \%$ of total seats in Senate (Kokpool, 2001, Vichit-Vadakan, 2008). I took some comparison to the last election result, 
the 1996 General Election, and the progress is quite surprising, the total was increased by 3,6\% , or 24 women MPs, and that was the biggest margin ever in the history of women representation in Thailand.

In my assumption, the implementation of gender equality article in 2001 General Election has impacted the advancement of women political representation in Parliament. I come with two other factors that might be intresting to be elaborated. First, the development of civil society in Thailand had succesfully influenced the constitutional making process. Second, the use of MMM as the new electoral system rather than SMC. I use Tremblay's proposition related to the increase of women representation which defined as the interaction of patrhiarcic value, Buddhism, Economic Crisis, and the implementation of gender equality article which also included the changes in electoral system.

As Tremblay's mentioned that the proportional system (Closed, Party-List) is more friendly towards women MP rather than majority system (single-member constituency). The Lower House has 500 seats, 400 of them will be elected through SMC, and 100 of them through PR System. 39 women MPs were elected via SMC (equal to $9,8 \%$ of total members in Lower House), while only 7 women whose elected through PR System ( equal to $7 \%$ of total). I conclude that SMC is not always bad for women MPs. The other variables such political ideologies, and quota could also detemined the advancement, yet Thailand still not recognized the quota or other affirmative action in their laws. Actually, there were such a movement led by Gender Development Research Institute (GDRI) which draw a petition to the House in order to push the affirmative action agenda, but it faced a failure (Tantiwiramanond, 2008). The advancement of women political participation can also be seen as the result of political opportunity structure. As POS views, economic crises has lead the NGOs in Thailand to the new level, and brought WCN as the main actor behind CDA and gender equality article.

\section{Epilogue: The Shifting Paradigm}

It took almost six decades for women to be recognized in Parliament since the first constitution. During that time, women's interest, at the best bet, was only represented through the politics of ideas (Phillips, 1995). It was not sufficient, women still need to be represented by themselves, the so-called politcs of presence. Women's presence in Parliament will define a new perspectives, will broaden their horizons, especially in policy making process.

I argue that Thai's women had faced the paradigm shifting. They are slowly yet sure, moving from merely politics of ideas, to the politics of presence. When women MPs has succesfully took strategic position such: Chairwoman, Vice-Chairwoman, Secretary, Treasurer, and Spokeswoman, it could be a sign that the Parliament is getting more sensitive towards women issues.

As my closing statement, Thailand's women is still need the supports from all stakesholders, together they can build a better advancement of women representation. The NGOs still need the openness, the most precious thing democracy could offer. The regime may leaves, democracy stays.

\section{REFERENCES}

Banks, Arthur S., et.al. (ed.). (2009). Political Handbook of The World 2009 (Washington D.C.: CQ Press.

Constitution of the Kingdom of Thailand B.E. 2540 (1997). Office of The Council of State (1997)

Iwanaga, Kazuki. (2005) Women in Politics in Thailand: Working Series Paper. Center for East and South-East Asia Studies, Lund University, Sweden.

Iwanaga, Kazuki. (2008). "Introduction: Women's Political Representation from an International Perspective", Kazuki Iwanaga (ed.), Women and Politics in Thailand: Continuity and Change (Copenhagen : NIAS Press.

Kokpol, Oratai, Electoral Politics in Thailand downloaded via http://library.fes.de/pdffiles/iez/01361006.pdf.

Kuhonta, Erik Martinez, "The Paradox of Thailand's 1997 "People's Constitution" : Be Careful What You Wish For", Asian Survey, Vol. 48, No. 3 (May/June 2008).

Nelson, Michael. (2001). "Thailand", Dieter Nohlen, et.al. (ed.) Elections in Asia and The 
PacificVol.II. New York: Oxford University Press.

Norris, Pippa. (2004). Electoral Engineering : Voting Rules and Political Behaviour, Cambridge : Cambridge University Press.

Ockey, James. (1997). "Thailand : The Crafting Democracy"Southeast Asian Affairs 1997. Singapore, ISEAS.

. (1999). "God Mothers, Good Mothers, Good Lovers, Godmothers : Gender Images in Thailand". The Journal of Asian Studies Vol.48 No.4.

Opp, Karl-Dieter. (2009). Theories of Political Protest and Social Movements : A Multidisciplinary Introduction, Critique and Synthesis.New York : Taylor \& Francis elibrary.

Philips, Ann. (1995). The Politics of Presence: The Political Representation of Gender, Ethnicity, and Race. Oxford: Clarendon Press.

Pongpaichit, Pasuk dan Chris Baker. (1997). Power in Transitions : Thailand in the 1990s", Kevin Hewison (ed.), Political Change in Thailand: Democracy and Participation. New York : Routledge.

Shigetomi, Shinichi. NGO as Political Actors in Thailand : Their Development and Strategies in Democratization and Human Rights Movements, downloaded via http://d-arch.ide.go.jp/infolib2/contents.

Smith, Harold E., et.al. (2005). Historical Dictionary of Thailand. Maryland : The Scarecrow Press.

Tantiwiramanond, Darunee dan Shashi Ranjan Pandey. (2008). Does Advocacy Matter? :Women's Advocacy Campaigns in Thailand. Bangkok: Freidrich-Erbert Stiftung.

Tremblay, Manon (ed.). (2008). Women and Legislative Representation: Electoral Systems, Political Parties, and Sex Quotas. New York: Palgrave Macmillan.

Vichit-Vadakan, Juree. (2008). Women in Politics and Women and Politics : A Socio-Cultural Analysis of the Thai Context dalam Women and Politics in Thailand, Kazuki Iwanaga (ed.), Copenhagen: NIAS Press.

Wasi, Prawase. (2002). "An Overview of Political Reform", Duncan McCargo (ed.), Reforming Thai Politics. Copenhagen: NIAS Press.

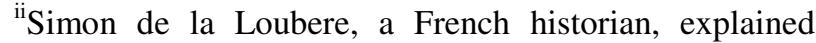
when he visited Thailand in the middle of 17th Century, women had become the lord of economics and trading. As Loubere written "the women plough tje land, and they sell and buy in the cities". From the sentence, I conclude that Thailand's women are actively engaged in public sphere, yet limited to economic activity. This role is getting developed by time, as Thai languange has its own term for mae kha, or female traders.

ii Women's Constitution Network (WCN) is a consortium of 35 women groups in Thailand. The main goal is to give advocacy for gender equality. They also played a crucial role during constitutional reform in 1997, and successfully accomodate the gender equality article

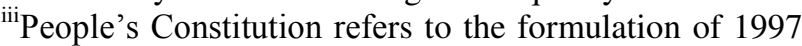
Constitution which opened more access to public to engage in ad-hoc institution called Constitution Drafting Assembly (CDA).

${ }^{\text {iv }}$ The recruitment and election process of CDA's members is using a mixed-methods, direct and in-direct. Each provinces have rights to nominate 10 candidates, which will selected by the Parliament. If there were more than 10 candidates in the province, they should held a preliminary election, top ten of the candidates will get the chance to next level. Thailand has 76 provinces, therefore there would be 760 candidates for CDA's members. Only 1 member that will become the representative for each provinces. 76 members from provincial representative will combined with 23 experts that had been appointed by the Parliament

${ }^{\mathrm{v}}$ The underground term was refer to the position of women movemnet during repressive military regime (1973-1976). The militer banned all forms of women activities, yet the activities were still going unbeknown by the military. 